\title{
SCIENTIFIC REPORTS

\section{On-farm multi-location evaluation of genotype by environment interactions for seed yield and cooking time in common bean}

\author{
Dennis N. Katuuramu ${ }^{1}$, Gabriel B. Luyima ${ }^{2}$, StanleyT. Nkalubo ${ }^{2}$, Jason A. Wiesinger ${ }^{1,3}$, \\ James D. Kelly ${ }^{1}$ \& Karen A. Cichy ${ }^{1,4^{*}}$
}

Common bean variety choice by farmers in Uganda is driven by seed yield plus end-use quality traits like market class and cooking time. Limited genotype by environment information is available for traits valued by consumers. This research evaluated yield, seed size, hydration properties, and cooking time of 15 common bean genotypes within market classes recognized by consumers along with three farmers' checks at nine on-farm locations in Uganda for two seasons. Yield ranged from 71 to $3,216 \mathrm{~kg} \mathrm{ha}^{-1}$ and was largely controlled by location (21.5\% of Total Sums of Squares [TSS]), plus the interaction between location and season ( $48.6 \%$ of TSS). Cooking time varied from 19 to 271 minutes with the genotypes Cebo Cela and Ervilha consistently cooking fastest in 24 and 27 minutes respectively. Comparatively, the local checks (NABE-4, NABE-15, and Masindi yellow) took 35 to 45 minutes to cook. Cooking time was largely controlled by genotype ( $40.6 \%$ of TSS). A GGE biplot analysis uncovered the presence of two mega-environments for yield and one mega-environment for cooking time. Identification of mega-environments for these traits will help expedite common bean breeding, evaluation, and variety selection through reduction of number of test environments needed for phenotype evaluations. The high yielding and fast cooking genotypes from this study can be targeted as parental materials to improve existing common bean germplasm for these important traits.

The world population is projected to reach 10 billion by the year 2050 and crop varieties that are resilient, productive, and nutritious under changing biotic and abiotic threats are urgently needed to meet the food security needs of the expanding population ${ }^{1}$. Common bean (Phaseolus vulgaris L.) is a widely grown and consumed staple crop in many parts of Latin America and Africa including Uganda ${ }^{2,3}$. In Eastern Africa, Uganda is the second largest producer of common bean and consumption provides $25 \%$ of the calories and $45 \%$ of the daily protein requirement $^{4}$. In Uganda, on-farm yields are often very low compared to those reported on research farms ${ }^{5}$. Reasons for the low on-farm yields include: (1) Use of poor-quality farmer saved seed; (2) Use of unimproved landrace genotypes that are susceptible to diseases and insect pests; (3) The poor soil fertility conditions and variable weather patterns in the production areas ${ }^{6}$. In Uganda and throughout Eastern Africa, farmers often place a greater value on end-use characteristics like seed color, seed size, flavor, and cooking time when compared to actual seed yield ${ }^{7}$.

Determining the degree of genotype by environment interactions for yield performance in common bean has been a major focus for plant breeders ${ }^{8}$. Seed yield performance is often measured through collaboration at University research sites, International Center for Tropical Agriculture and the National Agricultural Research System. However, there is limited information on studies conducted on farms owned and managed by the common bean growers ${ }^{8}$. On-farm participatory evaluation of genotype and genotype by environment interactions can identify novel germplasm suited for specific agro-ecological conditions, as previously demonstrated for rice in India ${ }^{9}$, sweet potatoes in Uganda and South Africa ${ }^{10,11}$, and cassava in Tanzania ${ }^{12}$. Genotypic yield performance is influenced by multiple genes interacting with biotic and abiotic stress factors over the course of the crop's growing

\footnotetext{
${ }^{1}$ Department of Plant, Soil and Microbial Sciences, Michigan State University, East Lansing, MI, 48824, USA. ${ }^{2}$ Legumes Research Program, National Crops Resources Research Institute, Namulonge, Kampala, Uganda. ${ }^{3}$ Present address: USDA-ARS, Robert W. Holley Center for Agriculture and Health, Cornell University, Ithaca, NY, 14853, USA. ${ }^{4}$ USDA-ARS, Sugarbeet and Bean Research Unit, Michigan State University, East Lansing, MI, 48824, USA. *email: karen.cichy@usda.gov
} 


\begin{tabular}{|c|c|c|c|c|c|c|c|c|c|}
\hline \multirow[b]{3}{*}{$\begin{array}{l}\text { Source of } \\
\text { variation }\end{array}$} & \multirow[b]{3}{*}{ df } & \multicolumn{8}{|l|}{ Traits } \\
\hline & & \multicolumn{2}{|l|}{ Yield $\left(\mathrm{kg} \mathrm{ha}^{-1}\right)$} & \multicolumn{2}{|c|}{ Seed weight (g) } & \multicolumn{2}{|c|}{$\begin{array}{l}\text { Water uptake } \\
(\%)\end{array}$} & \multicolumn{2}{|c|}{$\begin{array}{l}\text { Cooking time } \\
(\mathrm{min})\end{array}$} \\
\hline & & Mean square & \begin{tabular}{|l|}
$\%$ \\
TSS
\end{tabular} & $\begin{array}{l}\text { Mean } \\
\text { square }\end{array}$ & $\begin{array}{l}\% \\
\text { TSS }\end{array}$ & $\begin{array}{l}\text { Mean } \\
\text { Square }\end{array}$ & \begin{tabular}{|l|}
$\%$ \\
TSS \\
\end{tabular} & $\begin{array}{l}\text { Mean } \\
\text { square }\end{array}$ & \begin{tabular}{|l|}
$\%$ \\
TSS
\end{tabular} \\
\hline G & 15 & $558104.2^{* *}$ & 4.8 & $1351.4^{* *}$ & 51.5 & $5516.3 * *$ & 45.4 & $12850.9^{* *}$ & 40.6 \\
\hline $\mathrm{L}$ & 8 & $4738947.6^{* * *}$ & 21.5 & $327.5^{* *}$ & 6.7 & $548.2 * *$ & 2.4 & $4502.0 * *$ & 7.6 \\
\hline $\mathrm{S}$ & 1 & $719139.3 * *$ & 0.4 & $515.1 * *$ & 1.3 & $1906.1^{* *}$ & 1.0 & $16324.3^{* *}$ & 3.4 \\
\hline GxL & 120 & $100884.9^{* *}$ & 6.9 & $16.0^{*}$ & 4.9 & $150.1^{* *}$ & 9.9 & $763.0 * *$ & 19.3 \\
\hline GxS & 15 & $169218.6^{* *}$ & 1.4 & $48.0^{* *}$ & 1.8 & $2997.9^{* * *}$ & 24.7 & $3606.8 * *$ & 11.4 \\
\hline LxS & 8 & 10706389.0 ** & 48.6 & $981.6 * *$ & 19.9 & $907.8^{* *}$ & 4.0 & $665.5 * *$ & 1.1 \\
\hline $\operatorname{rep}(\mathrm{LxS})$ & 18 & $146755.7 * *$ & 1.5 & $16.2 \mathrm{NS}$ & 0.7 & $47.8^{*}$ & 0.5 & $55.3 \mathrm{NS}$ & 0.2 \\
\hline GxLxS & 120 & $100468.7^{* *}$ & 6.8 & $18.6^{* * *}$ & 5.7 & $136.3 * *$ & 9.0 & $549.6 * *$ & 13.9 \\
\hline
\end{tabular}

Table 1. ANOVA showing mean squares and percentage of total variance explained for yield, seed weight, water uptake, and cooking time of the common bean genotypes evaluated for two field seasons at the nine on-farm locations in Uganda. df: degrees of freedom; Significance level: *P value $<0.01 ; * * \mathrm{P}$ value $<0.001$; NS = not significant; \% TSS: Percentage of TSS explained.

season $^{13}$. Additionally, evaluation of germplasm on farmers' fields enables plant breeders to determine crop genotype performance amidst natural disease and pest pressures in the target locations ${ }^{14}$.

Recent studies in Uganda have revealed that common bean farmers attach equal value to both agronomic performance and end-use quality traits ${ }^{15,16}$. Therefore, new common bean varieties for Uganda must have improvements for both seed yield and end-use quality traits. One important end-use quality trait in common bean is cooking time because the crop often requires large amounts of heat energy to cook before consumption ${ }^{17}$. A large proportion of the population in Eastern Africa use either fuelwood or charcoal as the primary source of energy for cooking ${ }^{18}$. The process of gathering (and purchasing) wood fuel for cooking is a labor-intensive and time-consuming activity for families especially those living in the rural communities ${ }^{19}$. Genetic variability for cooking time exists in common bean and there is potential to improve this trait in new varieties belonging to the market classes recognized by the consumers ${ }^{20,21}$.

Cooking time has been shown to be highly heritable with limited effects of genotype by environment interactions $^{22,23}$. On-farm trials that include cooking time evaluation offer numerous advantages, including direct feedback about the harvested materials from the end users. Additionally, the approach allows for measurement of genotype performances at the actual environments where the future common bean varieties will be released for adoption, production, consumption, and marketing ${ }^{24}$.

Given common bean's wide range adaptation and importance as a food and nutrition security crop, our study evaluated the magnitude of genotype plus genotype by environment responses for seed yield, seed size, water uptake, and cooking time traits in 15 common bean test genotypes across nine on-farm locations spanning three agro-ecological zones in Uganda. The test genotypes were evaluated along with the farmers' local check varieties. Local check varieties were included to serve as benchmarks for each measured trait and determine the overall potential value of the test genotypes as parental materials to improve common bean for the aforementioned traits.

\section{Results}

ANOVA and broad-sense heritability. Results of the analysis of variance (ANOVA) for all traits are presented in Table 1.

Agronomic traits. The most important source of variation for seed yield was location (21.5\% of total sums of squares [TSS]) and the interaction component between location and season (48.6\% of TSS) (Table 1). Seed weight was largely controlled by genotype (51.5\% of TSS) followed by location by season interaction (19.9\% TSS) (Table 1). Broad-sense heritability $\left(\mathrm{H}^{2}\right)$ estimates for all traits ranged from 46.8 to $96.5 \%$. Seed yield had a moderate heritability estimate of $69.7 \%$ while seed weight had a high broad-sense heritability estimate of $96.5 \%$.

Hydration properties and cooking time. The ANOVA for water uptake showed that genotype and the interaction term between genotype and season were the major sources of variation as they accounted for 45.4 and $24.7 \%$ of TSS respectively (Table 1). Cooking time was controlled to a large extent by genotype (40.6\% of TSS) followed by genotype by location ( $19.3 \%$ of TSS) (Table 1$)$. Cooking time had a moderately high broad sense heritability estimate of $70.3 \%$.

\section{Evaluation of Genotype and Environment Performances}

Agronomic traits. Seed yield among genotypes ranged from 71 to $3,216 \mathrm{~kg} \mathrm{ha}^{-1}$ (Supplementary Table S2). The highest seed yield was recorded for genotypes G8 (Chijar) from the Caribbean and G5 (Amarelo Cela) - a landrace from sub-Saharan Africa (Table 2). The two highest yielding genotypes had an indeterminate growth habit. The third highest yielding genotype G3 (PI527538), is a yellow landrace also from sub-Saharan Africa with a determinate growth habit. Genotypes G12 (Uyole 96), G4 (Cebo Cela) and G13 (Charlevoix) produced significantly lower yields (Table 2). All the local check genotypes (NABE-15, NABE-4, and Masindi yellow) had yields lower than the top three genotypes of Chijar, Amarelo Cela, and PI527538 (Table 2). 


\begin{tabular}{|l|l|l|l|l|l|}
\hline Genotype code & Genotype name & $\begin{array}{l}\text { Yield }(\mathbf{k g} \\
\left.\mathbf{h a}^{-1}\right)\end{array}$ & $\begin{array}{l}\text { Seed weight } \\
(\mathbf{g})\end{array}$ & $\begin{array}{l}\text { Water } \\
\text { uptake (\%) }\end{array}$ & $\begin{array}{l}\text { Cooking time } \\
(\mathbf{m i n})\end{array}$ \\
\hline G1 & Blanco Fanesquero & 593 & 45.3 & 111.5 & 28.2 \\
\hline G2 & Ervilha & 671 & 42.2 & 119.3 & 27.0 \\
\hline G3 & PI527538 & 786 & 40.1 & 106.8 & 43.9 \\
\hline G4 & Cebo Cela & 531 & 35.2 & 114.6 & 24.6 \\
\hline G5 & Amarelo Cela & 910 & 26.6 & 71.2 & 96.5 \\
\hline G6 & Maalasa & 628 & 40.1 & 113.0 & 35.8 \\
\hline G7 & Rozi Koko & 589 & 42.4 & 114.9 & 32.8 \\
\hline G8 & Chijar & 929 & 25.0 & 99.8 & 53.8 \\
\hline G9 & Vazon 7 & 645 & 30.4 & 90.4 & 65.0 \\
\hline G10 & PR0737-1 & 709 & 34.2 & 110.7 & 72.4 \\
\hline G11 & Kidungu & 561 & 34.1 & 101.1 & 44.8 \\
\hline G12 & Uyole 96 & 525 & 44.7 & 107.3 & 41.3 \\
\hline G13 & Charlevoix & 536 & 41.6 & 122.1 & 48.9 \\
\hline G14 & Selian 97 & 714 & 35.2 & 113.9 & 33.1 \\
\hline G15 & Sacramento & 587 & 40.3 & 113.1 & 43.1 \\
\hline G16 & NABE-15 & 735 & 40.5 & 103.7 & 35.7 \\
\hline Check-2 & NABE-4 & 472 & 44.7 & 108.6 & 38.2 \\
\hline Check-3 & Masindi yellow & 439 & 37.6 & 115.4 & 45.6 \\
\hline LSD $(\boldsymbol{\alpha}=\mathbf{0 . 0 5})$ & & $\mathbf{1 0 7}$ & $\mathbf{1 . 5}$ & $\mathbf{2 . 1}$ & $\mathbf{3 . 0}$ \\
\hline
\end{tabular}

Table 2. Genotype means for the observed traits of the common bean genotypes evaluated across nine field sites for two years in Uganda. LSD: Least significant difference used to compare genotype performances for the measured traits; G16 denotes the NABE-15 local check-1 variety that was grown at locations KA, TU, KY, GE, $\mathrm{KV}$, and BA. NABE-4 was evaluated at location AG while Masindi yellow was grown at locations KU and TW.

\begin{tabular}{|l|l|l|l|l|}
\hline Location code & $\begin{array}{l}\text { Yield } \\
\left(\mathbf{k g ~ h a}^{-1}\right)\end{array}$ & $\begin{array}{l}\text { Seed } \\
\text { weight }(\mathbf{g})\end{array}$ & $\begin{array}{l}\text { Water } \\
\text { uptake (\%) }\end{array}$ & $\begin{array}{l}\text { Cooking } \\
\text { time }(\mathbf{m i n})\end{array}$ \\
\hline KA & 897 & 37.6 & 111.9 & 43.0 \\
\hline KY & 695 & 34.4 & 110.7 & 50.6 \\
\hline TU & 981 & 35.4 & 109.2 & 44.2 \\
\hline KU & 350 & 34.8 & 105.8 & 38.6 \\
\hline TW & 336 & 37.1 & 103.7 & 65.9 \\
\hline GE & 666 & 38.4 & 103.4 & 42.4 \\
\hline AG & 418 & 39.2 & 107.9 & 44.9 \\
\hline KV & 1057 & 41.5 & 106.2 & 39.5 \\
\hline BA & 637 & 37.9 & 106.9 & 41.1 \\
\hline $\begin{array}{l}\text { LSD } \\
(\boldsymbol{\alpha}=\mathbf{0 . 0 5})\end{array}$ & $\mathbf{8 0}$ & $\mathbf{1 . 2}$ & $\mathbf{1 . 6}$ & $\mathbf{2 . 3}$ \\
\hline
\end{tabular}

Table 3. Environmental means for the measured traits across the common bean genotypes evaluated at nine on-farm field sites for two years in Uganda. LSD: Least significant difference used to compare environmental performances for the measured traits.

Differences in environmental mean performance were large for yield with values ranging from 336 to $1,057 \mathrm{~kg} \mathrm{ha}^{-1}$. Location KV in Rakai district had the highest yield performance followed by locations KA and TU from Hoima district (Table 3). Seed yield was lowest at TW and KU locations both from Kamuli district. These locations had drier growing seasons and also had high disease pressure especially from common bean bacterial blight (Xanthomonas axonopodis pv. phaseoli) and bean common mosaic virus (a member of the Potyvirus).

Seed weight varied from 19-63 g per 100 seeds (Supplementary Table S3). The highest seed weight was observed among genotypes G1 (Blanco Fanesquero), G12 (Uyole 96), NABE-4, and G7 (Rozi Koko). The lowest seed weight values were observed among genotypes G8 (Chijar), G5 (Amarelo Cela), and G9 (Vazon 7) (Table 2). All the genotypes with the highest seed weight mean values (Blanco Fanesquero, Uyole 96, Rozi Koko, and Ervilha) had a determinate growth habit. The smallest seed weight values were recorded among genotypes Chijar, Amarelo Cela, and Vazon 7 which had an indeterminate growth habit (Tables 2 and 4). The local check genotypes had seed sizes ranging from 37.6 to $44.7 \mathrm{~g}$ per 100 seeds (Table 2). Seed weight was highest among genotypes grown at locations KV and AG in Rakai district (Table 3). The smallest seeds were produced at locations KY and KU from Hoima and Kamuli district respectively (Table 3). 


\begin{tabular}{|c|c|c|c|c|c|c|c|}
\hline $\begin{array}{l}\text { Genotype } \\
\text { code }\end{array}$ & Genotype name & $\begin{array}{l}\text { Gene } \\
\text { pool }\end{array}$ & Region of origin & $\begin{array}{l}\text { Country of } \\
\text { origin }\end{array}$ & $\begin{array}{l}\text { Cultivation } \\
\text { status }\end{array}$ & Seed type & Growth habit \\
\hline G1 & Blanco Fanesquero & Andean & South America & Ecuador & Variety & White & Determinate \\
\hline G2 & Ervilha & Andean & Southern Africa & Angola & Landrace & Yellow & Determinate \\
\hline G3 & PI527538 & Andean & East Africa & Burundi & Landrace & Yellow & Determinate \\
\hline G4 & Cebo Cela & Andean & Southern Africa & Angola & Landrace & Yellow & Indeterminate \\
\hline G5 & Amarelo Cela & MA & Southern Africa & Angola & Landrace & Yellow & Indeterminate \\
\hline G6 & Maalasa & Andean & East Africa & Tanzania & Landrace & Red mottled & Determinate \\
\hline G7 & Rozi Koko & Andean & East Africa & Tanzania & Landrace & Red mottled & Determinate \\
\hline G8 & Chijar & MA & Caribbean & Puerto Rico & Landrace & Red mottled & Indeterminate \\
\hline G9 & Vazon 7 & MA & Caribbean & Puerto Rico & Landrace & Red mottled & Indeterminate \\
\hline G10 & PR0737-1 & Admix & Caribbean & Puerto Rico & Variety & Red mottled & Indeterminate \\
\hline G11 & Kidungu & Andean & East Africa & Tanzania & Landrace & Small red & Determinate \\
\hline G12 & Uyole 96 & Andean & East Africa & Tanzania & \begin{tabular}{|l|} 
Variety \\
\end{tabular} & DRK & Determinate \\
\hline G13 & Charlevoix & Andean & North America & U.S. & Variety & DRK & Determinate \\
\hline G14 & Selian 97 & Andean & East Africa & Tanzania & Variety & DRK & Determinate \\
\hline G15 & Sacramento & Andean & North America & U.S. & Variety & LRK & Determinate \\
\hline \multicolumn{8}{|c|}{ G16 -Local Checks } \\
\hline Check-1 & NABE-15 & Andean & East Africa & Uganda & Variety & Cream mottled & Determinate \\
\hline Check-2 & NABE-4 & Andean & East Africa & Uganda & Variety & Red mottled & Determinate \\
\hline Check-3 & Masindi yellow & Andean & East Africa & Uganda & Landrace & Yellow & Determinate \\
\hline
\end{tabular}

Table 4. Description of the experimental common bean genotypes evaluated over two years across nine onfarm locations in Uganda. MA: Middle American; DRK: Dark red kidney; LRK: Light red kidney.

Water uptake and cooking time. Seed water uptake after soaking varied from 18.7 to $149.1 \%$ (Supplementary Table S4). Genotypes G13 (Charlevoix) and G2 (Ervilha) absorbed the most water while accessions G5 (Amarelo Cela) and G9 (Vazon 7) absorbed the least amount of water (Table 2). The genotypes grown at locations KA and KY in the Hoima district imbibed the most water (Table 3). Genotypes harvested from locations GE and TW in Kamuli district had the lowest water absorption (Table 3).

Cooking time among genotypes varied from 19.4 to 270.6 minutes (Supplementary Table S5). Genotypes with the longest cooking times were G5 (Amarelo Cela), G10 (PR0737-1), and G9 (Vazon 7) (Table 2). The longest cooking genotype Amarelo Cela was a yellow bean landrace collected from Angola (Table 2). Amarelo Cela (G5) and Vazon 7 (G9) also absorbed the least amount of water during soaking and the low water uptake likely contributed to the longer cooking times observed for these genotypes. The fastest cooking genotypes G4 (Cebo Cela) and G2 (Ervilha) are both African Manteca yellow common bean landraces collected from Angola and G1 (Blanco Fanesquero) is a white grain colored variety from Ecuador (Table 2). The local check genotypes had average cooking times ranging from 35.7 to 45.6 minutes (Table 2). Cooking time averages varied across locations. Genotypes grown at location TW in Kamuli district required the longest time to cook (65.9 minutes) while genotypes grown at sites KU and KV had the shortest cooking times of 38.6 and 39.5 minutes respectively (Table 3 ).

Polygon ("which-won-where") View of the GGE Biplots

Seed yield and seed weight. The polygon view of the GGE biplot explained 68 and $94.6 \%$ of the genotype plus genotype by environment variation for seed yield and seed weight respectively (Fig. 1: Panels A and B). The GGE biplot analysis for yield resulted in two sectors indicating presence of two winning genotypes of G8 (Chijar) and G5 (Amarelo) for each sector. The presence of two sectors also confirms presence of genotype by environment interaction and two mega-environments for seed yield (Fig. 1A). The first mega-environment had locations $\mathrm{KY}, \mathrm{TU}, \mathrm{KV}$, and TW while sites $\mathrm{KA}, \mathrm{AG}, \mathrm{BA}, \mathrm{GE}$, and $\mathrm{KU}$ formed the second mega-environment (Fig. 1A). The test environments clustered in two groups for seed weight implying presence of two mega-environments (Fig. 1B). The first mega-environment for seed weight was comprised of locations GE, KA, KV, KU, TW, KY, and TU. The second mega-environment had locations BA and AG (Fig. 1B).

Water uptake and cooking time. The GGE biplot explained 93.7 and $95.1 \%$ of the genotype plus genotype by environment variation for water uptake and cooking time respectively (Fig. 2: Panels A and B). The locations clustered into two sectors for water uptake indicating the presence of two mega-environments (Fig. 2A). Eight of the nine locations made one mega-environment (Fig. 2A). All the environments clustered in one sector (one mega-environment) for cooking time with one clear slow-cooking genotype G5 (Amarelo Cela) and the fastest cooking genotype was G4 (Cebo Cela) (Fig. 2B).

\section{Genotype Mean Performance vs. Stability GGE Biplots}

Seed yield and seed weight performance. Genotypes trending towards the direction of G5 (Amarelo Cela) and G8 (Chijar) denote higher yielding and genotypes trending towards the opposite direction represent the poor performing lines like G4 (Cebo Cela) and G12 (Uyole 96) (Fig. 3A). Genotypes G6 (Maalasa) and G11 (Kidungu) were the most stable as they had near zero projection from the AEC horizontal axis. Genotypes G8 (Chijar) and G2 (Ervilha) are regarded as the least stable for yield performance since they exhibited the longest 
A

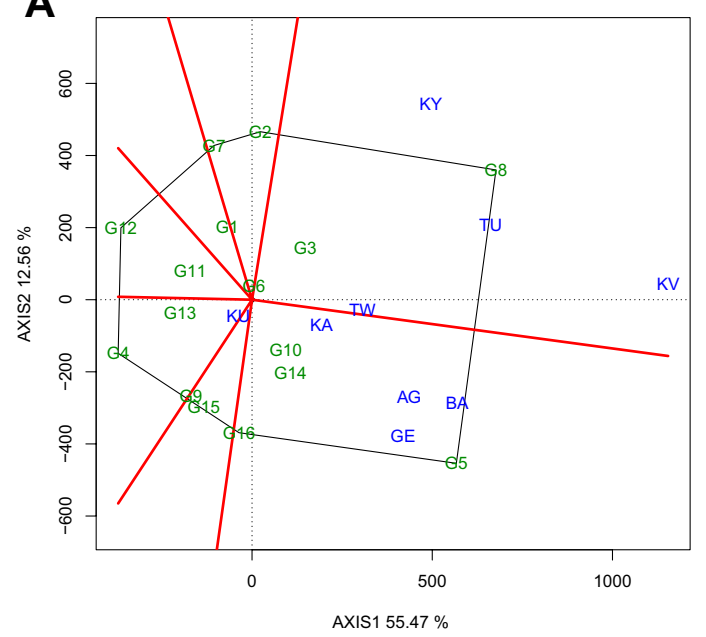

B

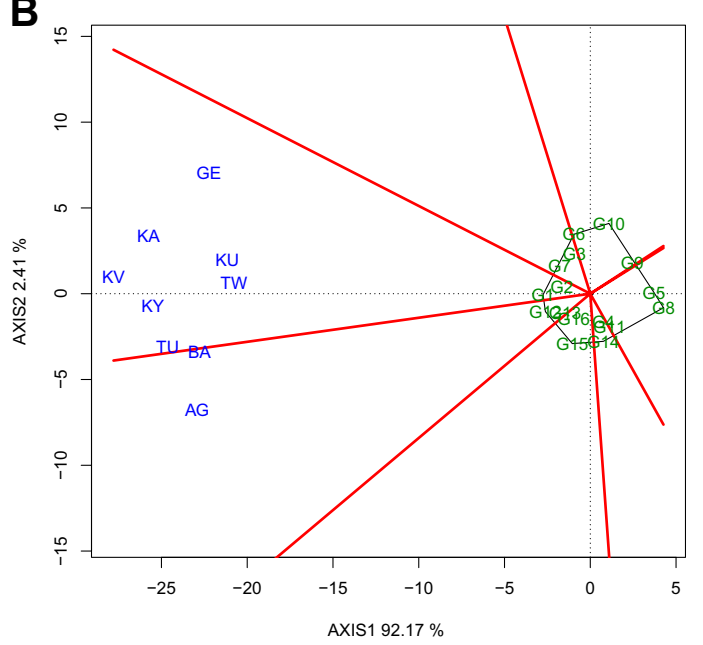

Figure 1. The polygon (which-won-where) view of genotype main effects plus genotype by environment interaction effect (GGE) biplot of the common bean genotypes evaluated for two years across nine on-farm locations for yield (A) and seed weight (B). The biplots were generated based on a Scaling $=0$, Centering $=2$, and $\mathrm{SVP}=2$. Key to the labels of locations and genotypes is presented in Tables 1 and 2 respectively.
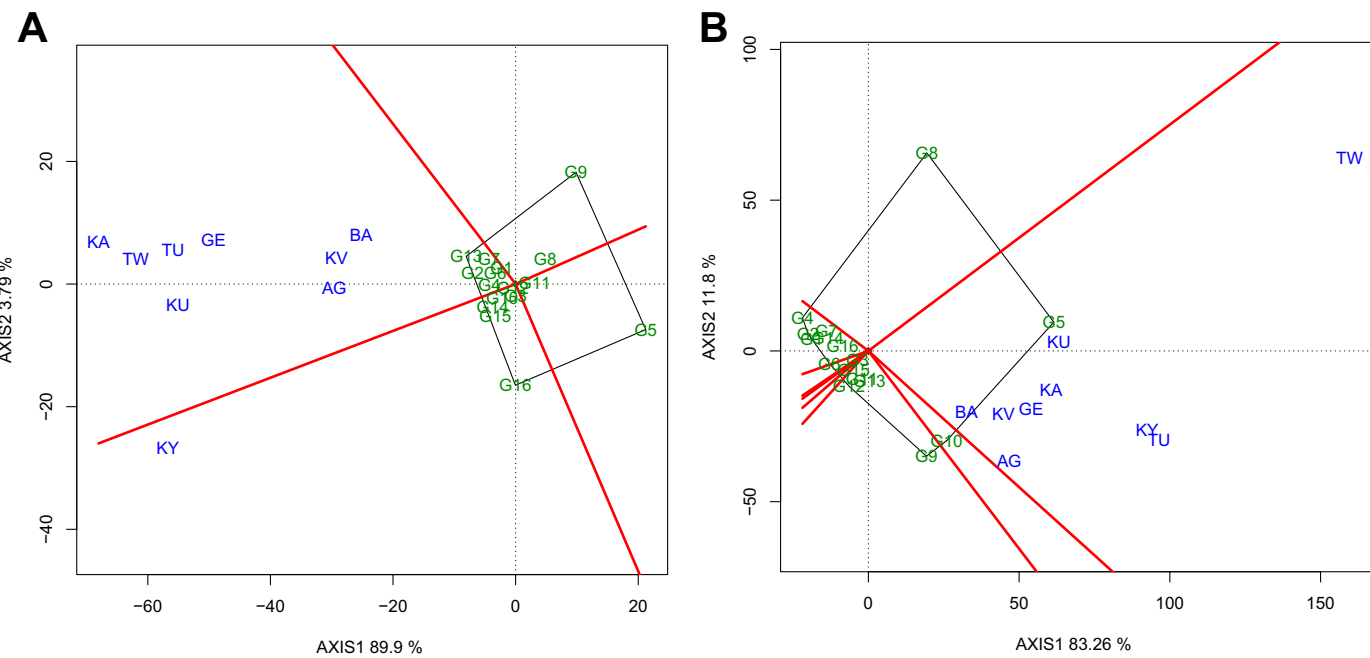

Figure 2. The polygon (which-won-where) view of genotype main effects plus genotype by environment interaction effect (GGE) biplot of the common bean genotypes evaluated for two years across nine on-farm locations for water uptake (A) and cooking time (B). The biplots were generated based on a Scaling $=0$, Centering $=2$, and SVP $=2$. Key to the labels of locations and genotypes is presented in Tables 1 and 2 respectively.

projection from the AEC horizontal axis (Fig. 3A). Genotypes in the direction of G1 (Blanco Fanesquero) and G12 (Uyole 96) had a larger seed size while genotypes in the direction of G5 (Amarelo Cela) and G8 (Chijar) had a smaller seed size (Fig. 3B). Genotypes G1 (Blanco Fanesquero), G2 (Ervilha), and G5 (Amarelo Cela) were the most stable for seed weight as they had a near zero projection from the AEC horizontal axis. The least stable genotypes for seed weight were G6 (Maalasa) and G10 (PR0737-1) as these exhibited the longest projections from the AEC horizontal axis (Fig. 3B). Genotypic performance instability (longer projections) can also indicate local adaptation, whereby genotypes located above or below the AEC horizontal axis would perform better at test environments located in identical orientations of the AEC axis.

Water uptake and cooking time. Genotypes in the direction of G2 (Ervilha) and G13 (Charlevoix) absorbed more water while genotypes in the direction of G9 (Vazon 7) and G5 (Amarelo Cela) had lower water uptake values (Fig. 4A). Most genotypes were stable for water uptake across locations except for G9 (Vazon 7) which had a long projection from the AEC horizontal axis (Fig. 4A). Genotypes in the direction of G10 (PR07371) and G5 (Amarelo Cela) were slow cooking while genotypes in the opposite direction along the AEC horizontal axis such as G1 (Blanco Fanesquero), G2 (Ervilha), and G4 (Cebo Cela) were fast cooking. The Manteca yellow 
A

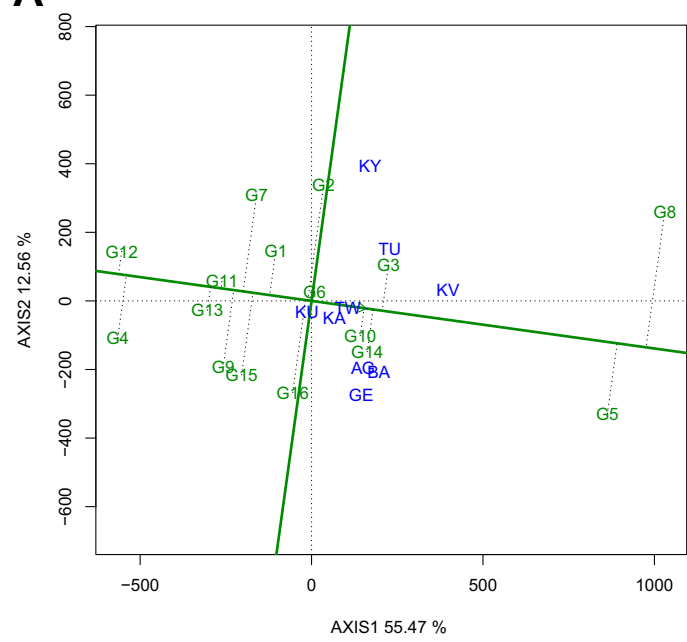

B

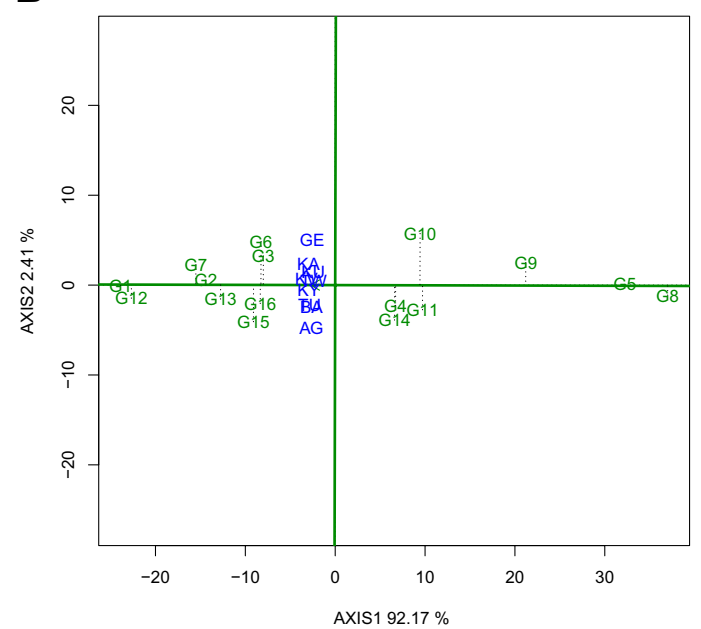

Figure 3. Mean performance vs. stability view of genotype main effects plus genotype by environment interaction effect (GGE) biplot of the common bean genotypes evaluated for two years across nine on-farm locations for yield (A) and seed weight (B). The biplots were generated based on a Scaling $=0$, Centering $=2$, and $S V P=1$. Key to the labels of locations and genotypes is presented in Tables 1 and 2 respectively.

A

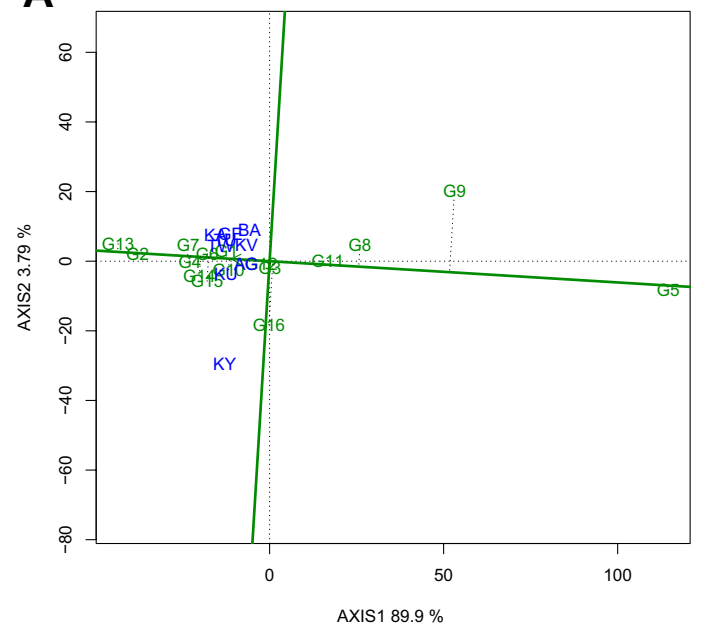

B

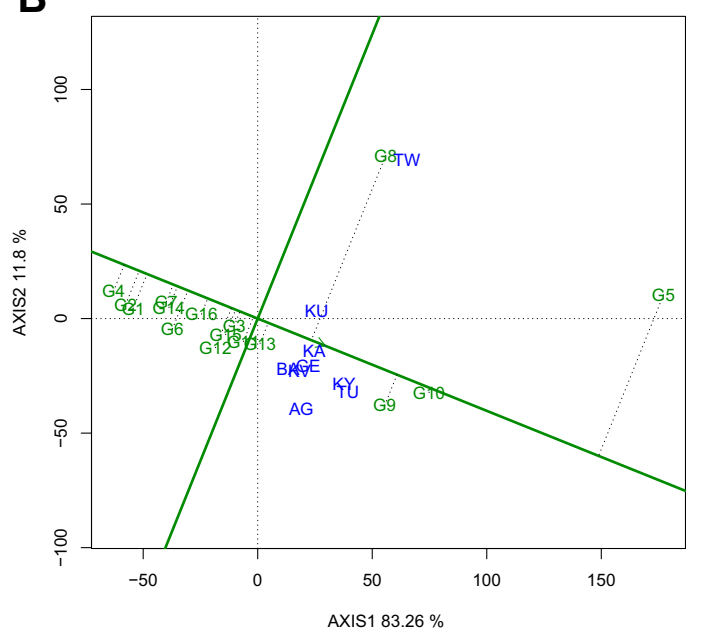

Figure 4. Mean performance vs. stability view of genotype main effects plus genotype by environment interaction effect (GGE) biplot of the common bean genotypes evaluated for two years across nine on-farm locations for water uptake (A) and cooking time (B). The biplots were generated based on a Scaling $=0$, Centering $=2$, and SVP $=1$. Key to the labels of locations and genotypes is presented in Tables 1 and 2 respectively.

bean Cebo Cela was the fastest cooking genotype in this study (Fig. 4B). Genotype G10 (PR0737-1) was the most stable for cooking time (with a near zero projection from the AEC horizontal axis) while accessions G8 (Chijar) and G5 (Amarelo Cela) were the least stable (Fig. 4B).

Correlations among traits. Pearson correlation coefficients indicated that seed yield was correlated to seed weight $(\mathrm{r}=0.219 ; P$ value $<0.0001)$. Seed weight was positively correlated to water uptake $(\mathrm{r}=0.271 ; P$ value $<0.0001)$ but negatively correlated to cooking time $(\mathrm{r}=-0.345 ; P$ value $<0.0001)$ (Table 5$)$. Water uptake was negatively correlated with cooking time $(\mathrm{r}=-0.667 ; P$ value $<0.0001)$ implying that soaked beans that absorbed the most water cooked faster (Table 5). 


\begin{tabular}{|l|l|l|l|l|}
\hline Traits & Yield & $\begin{array}{l}\text { Seed } \\
\text { weight }\end{array}$ & $\begin{array}{l}\text { Water } \\
\text { uptake }\end{array}$ & $\begin{array}{l}\text { Cooking } \\
\text { time }\end{array}$ \\
\hline Yield & - & $0.219^{*}$ & -0.059 NS & -0.003 NS \\
\hline Seed weight & & - & $0.271^{*}$ & $-0.345^{*}$ \\
\hline Water uptake & & & - & $-0.667^{*}$ \\
\hline
\end{tabular}

Table 5. Pearson correlation coefficients among traits across the nine on-farm locations and two field seasons. *Significant at the 0.0001 probability level; NS = not significant.

\section{Discussion}

In Uganda, common bean is the most important legume as the crop can thrive in a wide range of agro-ecological zones $^{25}$. Small seeded black Middle American common bean genotypes with indeterminate growth habits are productive in the drier parts of Northern Uganda such as Arua district. In the cooler mountainous regions of Southwestern Uganda farmers typically grow the Type IV large-seeded common bean varieties. These tend to be aggressive climbers and are often intercropped with maize for support ${ }^{26}$. The most widely grown and consumed beans in Uganda are Andean determinate types of the red mottled, yellow, and cream-colored market classes and these are grown across the Eastern, Central, and Western regions of Uganda ${ }^{27,28}$. The Andean determinate genotypes typically have a lower yield potential compared to the indeterminate Middle American accessions, but their shorter growing season and large seed sizes make them appealing to farmers and consumers ${ }^{20}$.

Five indeterminate genotypes were evaluated in this study along with the 12 determinate genotypes. The indeterminate genotypes were included since they had seed types within the scope of this study (i.e. red mottled and yellow). The two top yielding varieties were both indeterminate Middle American small-seeded genotypes. While these genotypes were all landraces with limited potential for direct release, their on-farm yield performance was similar to previous reports that showed indeterminate Middle American germplasm to produce higher yields and can thus be used as parents in breeding crosses to improve the determinate common bean types.

Both location and location by season components were important sources of variation for seed yield. Seed yield in common bean is a highly complex trait and affected by environmental factors ${ }^{29,30}$. There were also large differences in mean performance for yield across locations due to variability in disease pressure and soil characteristics with non-tropical varieties from North American being the most susceptible. Location TW in Kamuli district had insufficient soil $\mathrm{NO}_{3}-\mathrm{N}$ and lowest yield performance of $336 \mathrm{~kg} \mathrm{ha}^{-1}$ demonstrating that soil fertility is a major challenge to common bean farmers in this region (Table 3; Supplementary Table S1).

The which-won-where GGE biplot is used to detect best performing genotypes in a group of environments or mega-environments for multi-environment field trials ${ }^{31}$. The polygon is generated by joining extreme genotypes in the study and perpendicular lines (rays) cutting through the sides of the polygon divide groups of genotypes and environments into sectors ${ }^{32}$. This study revealed presence of two mega environments for yield (Fig. 1A). Mega-environment identification has vital implications with regards to selection of test locations for genotype evaluation, selection, and release in modern breeding programs. Based on the results, the evaluation of genotypes for yield performance in Uganda should be conducted in two mega-environments.

Variability for seed weight in this study was largely controlled by genetics (51.5\% of TSS). In common bean, seed size is strongly tied to gene pool structure. Andean genotypes are usually larger when compared to genotypes from the Middle America gene pool ${ }^{33}$. Most of the determinate genotypes were large kidney seed types weighing over $35 \mathrm{~g}$ per 100 seeds, which is a typical seed size among the large seeded Andean common bean ${ }^{34}$. Seed size along with cooking time and seed type are important end-use attributes valued by consumers in Uganda ${ }^{15}$. Identification of germplasm having large and stable seed size performance will help accelerate targeted development of common bean ideotypes that have traits important to farmers and consumers.

Hydration properties as measured by water uptake after 12-hour soaking, is an important parameter to evaluate seed quality in common bean. Typically, seeds will take up water at least $90 \%$ of their weight during a 12-hour soaking period. Hardshell is a phenomenon used to describe beans that take up insufficient water during soaking $^{35}$. Hardshell is induced under semi-arid environmental conditions during seed fill and maturation and dry storage conditions $s^{36}$. Some genotypes are more susceptible to hardshell than others ${ }^{37}$. Hardshell is one reason for long cooking times, but it can often be reversed by storing harvested common bean seeds at $\sim 68 \%$ relative humidity before cooking ${ }^{38}$. Genotypes G5 (Amarelo Cela), G8 (Chijar), and G9 (Vazon 7) that all belong to the Middle American gene pool were the most susceptible to the hardshell condition in this study. Genotypes grown at locations TW and GE in Kamuli district exhibited more hardshell defect as they imbibed the least amount of water.

Genotypes G5 (Amarelo Cela), G8 (Chijar), and G9 (Vazon 7) were also among the longest cooking accessions, showing that water uptake may be a useful predictor of long cooking time, although not always since G10 (PR0737-1) also had the second longest cooking time but still absorbed 110.7\% water following a 12-hour soak. Therefore, genotype G10 (PR0737-1) likely has a different mechanism for long cooking time that is not related to the seed coat but could be related to its cotyledon structure. The longest cooking genotype G5 (Amarelo Cela) was a yellow grain colored landrace from Angola (Table 2). Interestingly, Katuuramu ${ }^{39}$ reported that genotype Amarelo Cela also accumulated the highest concentration of seed calcium. Presence of free calcium ions in the seed has been reported to form crosslinks with cell wall polysaccharides resulting in reduced cell separation and longer cooking times ${ }^{40,41}$.

The three fastest cooking genotypes G1 (Blanco Fanesquero), G2 (Ervilha), and G4 (Cebo Cela) cooked at least 10 minutes faster than the farmers' local checks, indicating a potential valuable germplasm source that can be deployed to breed for fast cooking common bean for Uganda. The strong influence of genotype and the lack of large genotype by environment interactions for this cooking time suggest that breeding and evaluation for 


\begin{tabular}{|c|c|c|c|c|c|c|c|c|c|}
\hline District & $\begin{array}{l}\text { Annual rainfall } \\
\text { range (mm) }\end{array}$ & $\begin{array}{l}\text { Annual temperature } \\
\text { range }\left({ }^{\circ} \mathrm{C}\right)\end{array}$ & Agro-ecological zone & Location & $\begin{array}{l}\text { Location } \\
\text { code }\end{array}$ & Geographic & coordinate & $\begin{array}{l}\text { Altitude } \\
\text { ( } \mathrm{m} \text { asl) }\end{array}$ & Soil type \\
\hline \multirow{3}{*}{ Hoima } & \multirow{3}{*}{$800-1,400$} & \multirow{3}{*}{$15-30$} & \multirow{3}{*}{ Grass land savanna } & Kakindo & KA & $\mathrm{N} 01^{\circ} 28.54^{\prime}$ & $\mathrm{E} 031^{\circ} 25.46^{\prime}$ & 1,228 & Sandy clay \\
\hline & & & & Kyamalera & KY & N01 ${ }^{\circ} 29.47^{\prime}$ & $\mathrm{E} 031^{\circ} 26.99^{\prime}$ & 1,174 & Sandy clay loam \\
\hline & & & & Tugonzagane & TU & $\mathrm{N} 01^{\circ} 16.93^{\prime}$ & $\mathrm{E} 031^{\circ} 17.77^{\prime}$ & 1,138 & Clay \\
\hline \multirow{3}{*}{ Kamuli } & \multirow{3}{*}{$800-1,300$} & \multirow{3}{*}{$16-31$} & \multirow{3}{*}{ Tall savanna } & Katugezeko & KU & $\mathrm{N}^{\circ}{ }^{\circ} 50.60^{\prime}$ & $\mathrm{E} 033^{\circ} 12.11^{\prime}$ & 1,127 & Clay loam \\
\hline & & & & Tweweyo & TW & $\mathrm{N}^{\circ} 0^{\circ} 54.79^{\prime}$ & $\mathrm{E} 033^{\circ} 01.33^{\prime}$ & 1,086 & Sandy clay loam \\
\hline & & & & Tweyunge & GE & N00 $53.77^{\prime}$ & E032 $59.94^{\prime}$ & 1,061 & Sandy clay loam \\
\hline \multirow{2}{*}{ Rakai } & \multirow{2}{*}{$850-2,125$} & \multirow{2}{*}{$15-27$} & \multirow{2}{*}{ Tropical rain forest } & Agali-awamu & AG & $\mathrm{S} 00^{\circ} 34.87^{\prime}$ & $\mathrm{E} 031^{\circ} 34.19^{\prime}$ & 1,233 & Sandy clay \\
\hline & & & & Kiyovu & KV & $\mathrm{S} 00^{\circ} 43.58^{\prime}$ & $\mathrm{E} 031^{\circ} 29.27^{\prime}$ & 1,215 & Sandy clay loam \\
\hline Masaka & $850-2,125$ & $15-27$ & Tropical rain forest & Balitwewunya & BA & $\mathrm{S} 00^{\circ} 25.54^{\prime}$ & E031 $38.14^{\prime}$ & 1,249 & Clay \\
\hline
\end{tabular}

Table 6. Description of the nine on-farm locations used for the common bean genotype by environment study in Uganda.

this trait can be carried out in fewer environments. In addition, the GGE biplot result showed presence of one mega-environment for cooking time (Fig. 2B) which further supports this recommendation.

The average environment coordinate (AEC) view (genotype mean performance vs. stability) allows for the comparison of genotypes based on estimates of genotype performance and stability across environments within a mega-environment ${ }^{42}$. Using this methodology, stability of genotypes is measured by the length of their projection from the AEC horizontal axis (shown by the dotted lines in Figs. 3 and 4). Ideally, genotypes with a near zero projection (e.g. absence of a dotted vertical line above or below the AEC horizontal axis) are declared stable ${ }^{42}$. Best performing genotypes for yield and seed weight were not stable across the nine on-farm locations (Fig. 3: Panels A and B). These findings show that genotypes responded differently to the existing soil nutrients, weather conditions, and endemic foliar disease pressures for each location, which further emphasize the strong influence of genotype by environment interactions on these agronomic traits. Projections from the AEC horizontal axes for the majority of the genotypes were shorter for water uptake and cooking time implying strong stability of these traits. For stability to be useful to plant breeders and growers, stable genotypes need to exhibit high trait performances and such results should be validated over multiple years of field evaluations ${ }^{32}$.

From a plant breeding perspective, correlation analysis can help identify positive or negative relationships among traits, identify novel parental combinations for variety development and detect trait measurement redundancy ${ }^{43}$. This study showed that yield was correlated to seed size. Previous studies have showed that increasing seed size results in a yield penalty and this has been one of the major limitations to yield improvements among genotypes in the Andean versus those in the Middle American gene pool ${ }^{33}$. No correlations were found between seed yield and water uptake or cooking time, suggesting that fast cooking varieties will not suffer a reduction in seed yield.

\section{Conclusions}

Common bean genotypes with higher yields than the local checks were identified, although these had smaller seed size and longer cooking times than the farmers' selected local checks. Fast cooking genotypes were also identified, including landraces G2 (Ervilha) and G4 (Cebo Cela), and the Ecuadorian white kidney variety G1 (Blanco Fanesquero) but none of the fastest cooking genotypes had higher yield than the preferred NABE-15 local check. There is a need to pyramid fast cooking and high yielding traits into a single genetic background and to evaluate preference of fast cooking genotypes among farmers and consumers. The moderate broad-sense heritability for on-farm seed yield and cooking time suggests phenotypic selection for these traits can allow for improvements in trait performances. With a single mega-environment for cooking time it is feasible that common bean germplasm evaluation and selection for this trait can be conducted in one or few test locations thus maximizing the value of resources available to the in-country breeding programs. On-farm varietal selection with farmers participation may be a well-suited strategy to identify fast cooking genotypes that appeal to growers and consumers.

\section{Materials and Methods}

Field study sites. The study was conducted at nine on-farm locations representing three agro-ecological zones across Hoima, Kamuli, Rakai, and Masaka districts in Uganda (Table 6). Hoima and Kamuli districts are located in Western and Eastern Uganda respectively. Both Rakai and Masaka districts are located in Central Uganda. These four districts were chosen because they represent areas of high common bean production, consumption, crop marketing, and selling. Both Kamuli and Hoima districts produce common bean largely for home consumption, while in Masaka and Rakai districts it is produced as both a food and cash crop ${ }^{27}$.

All study locations receive bimodal rainfall with the first rains falling from March to May while the second rainy season is from mid-September to early December. Hoima district receives rainfall ranging from 800 to $1,400 \mathrm{~mm}$ per year with temperature ranges of 15 to $30^{\circ} \mathrm{C}^{44}$. Kamuli district receives an annual rainfall ranging from 800 to $1,300 \mathrm{~mm}$ with temperatures ranging from 16 to $31^{\circ} \mathrm{C}^{44}$. Both Masaka and Rakai districts are located near Lake Victoria in Central Uganda and these districts receive an annual rainfall ranging from 850 to $2,125 \mathrm{~mm}$. The annual temperature varies from 15 to $27^{\circ} \mathrm{C}^{44,45}$. Across each of the on-farm locations variable amounts of rainfall, fluctuating number of rain days, and increasing changes in temperatures of 0.5 to $0.9^{\circ} \mathrm{C}$ have been recently reported by Mubiru ${ }^{44}$. 
Before planting, soil samples were collected from a soil layer depth of 0-to-30 $\mathrm{cm}$ at each of the nine on-farm sites for field seasons 2015 and 2016. The composite soil cores from each site were mixed and allowed to air-dry separately in Uganda, then shipped to the Soil and Plant Nutrient Laboratory at Michigan State University (http:// www.spnl.msu.edu) for evaluation of nutrient composition. Soil fertility analysis was conducted to measure $\mathrm{pH}$, organic matter $(\mathrm{OM})$, nitrate-nitrogen $\left(\mathrm{NO}_{3}-\mathrm{N}\right)$, Bray-1 extractable phosphorus $(\mathrm{P})$, potassium $(\mathrm{K})$, and calcium (Ca) based on previously published protocols ${ }^{4}$.

The soils in Hoima district were sandy clay at KA, sandy clay loam at KY, and clay at TU. Soils in Kamuli district were clay loam for site KU, and sandy clay loam for both locations TW and GE. In Rakai district, AG had sandy clay while KV had sandy clay loam soils. Location BA in Masaka district had clay soils (Supplementary Table S1). The soils at each location had $\mathrm{pH}$ values ranging from 5.0 to 7.1 with locations in Rakai and Masaka districts (AG, KV, BA) having the most acidic soils with $\mathrm{pH}$ values ranging from 5.0 to 5.6 (Supplementary Table S1). One location in both Hoima (KY) and Kamuli (GE) had elevated soil pH levels over both years (Supplementary Table S1).

Most locations except TW (2016), AG (2015), and KV (2016) had organic matter greater or equal to 3\% (Supplementary Table S1). Majority of the locations except KA and KY (both 2016), TW (2015 and 2016), and $\mathrm{KV}$ (2016) had sufficient soil $\mathrm{NO}_{3}-\mathrm{N}$ with readings above $11 \mu \mathrm{gg}^{-1}$ which are considered optimum for common bean production. Soil P concentration ranged from $6-36 \mu \mathrm{g} \mathrm{g}^{-1}$ across all locations. Most sites except KY (2016) and BA (2015) had soil P levels below the optimum value of $36 \mu \mathrm{gg}^{-1}$ required for good crop productivity on agricultural soils (Supplementary Table S1). Soil K concentrations ranged from $28-531 \mu \mathrm{g} \mathrm{g}^{-1}$ for the nine on-farm locations over the two field seasons. Soil K levels of $144 \mu \mathrm{g} \mathrm{g}^{-1}$ are sufficient for crop growth, and several locations did not meet this level of soil K for the 2015 and 2016 field seasons (Supplementary Table S1). In both years, soil Ca concentrations were not limiting at the nine on-farm locations with values above the $400 \mu \mathrm{gg}^{-1} \mathrm{minimum}$ cutoff that is desired for good crop performance (Supplementary Table S1).

Common bean germplasm. The genotypes were chosen from a large Andean Diversity Panel (http://arsftfbean.uprm.edu/bean/) germplasm of over 200 lines previously field-grown in Montcalm, Michigan, USA in 2012 and 2013. The panel has been characterized for cooking time, seed mineral concentration, and iron bioavailability $^{20,47}$. Genotypes targeted for inclusion in the 15-germplasm set had variable cooking times (from fast to slow cooking), iron ( $\mathrm{Fe})$ concentrations greater than $70 \mu \mathrm{gg}^{-1}$ and zinc $(\mathrm{Zn})$ concentrations greater than $30 \mu \mathrm{gg}^{-1} \mathrm{on}$ a dry weight basis ${ }^{20,47}$. Three of the genotypes were dark red kidney, four were yellow, five were red mottled, and there was one genotype from each of the white, small red, and light red kidney seed market classes. Most of the yellow and white colored genotypes were faster cooking and had higher Fe bioavailability when compared to the dark red kidney and red mottled accessions. The red mottled genotypes were particularly slower cooking but had higher concentrations of $\mathrm{Fe}$ and $\mathrm{Zn}^{20,47}$.

The local check NABE-15 (Kanyebwa) is a cream mottled common bean variety that is popular with farmers in Uganda and was grown at six locations (KA, TU, KY, GE, KV, BA) for field seasons 2015 and 2016. NABE-15 was released in 2010 by National Crops Resources Research Institute (NaCRRI) of Uganda with the attributes of high yield, fast cooking, and anthracnose resistance ${ }^{48,49}$. Locations KU and TW were planted with the Masindi yellow local check, which is an old landrace preferred for its taste and fast cooking attributes. The local check NABE-4 (Nambale omuwanvu) was grown in AG and was also released by NaCRRI in 1999. NABE-4 is a large red mottled variety described as fast cooking, drought tolerant, and high yielding ${ }^{49}$. Eleven genotypes and all local checks had type I determinate growth habit while the other five genotypes were indeterminate (Table 4).

Field plot design. The experiment was conducted as a randomized complete block design with two field replications for all genotypes at the nine on-farm locations. Each genotype plot was comprised of five rows that were $3.5 \mathrm{~m}$ long with $0.5 \mathrm{~m}$ between row length. The entire five-row genotype plot was planted with 220 seeds. The study was conducted for two field seasons during the long rainy season of 2015 (September - through early December) and the shorter 2016 rainy season (March to May). Planting was initiated at the onset of rains (first week of September in 2015) and (first week of March in 2016). At planting, a light application of starter fertilizer containing nitrogen, phosphorus, and potassium (NPK: 17-17-17) was applied at a rate of $125 \mathrm{~kg} \mathrm{ha}^{-1}$ to all sites in both field seasons. During each growing season the research plots were kept weed-free by two cycles of hand-weeding at 30- and 45-days post-planting. The trial plots were harvested and threshed by hand and all harvesting was completed by the first week of December in 2015 and third week of June in 2016.

Phenotyping for common bean agronomic traits. Seed yield was collected on all harvested genotypes from a research plot area of $7 \mathrm{~m}^{2}$ and converted to $\mathrm{kg} \mathrm{ha}^{-1}$. Seed weight was collected by counting 100 seeds and measuring their weight in grams.

Phenotyping for hydration properties (water uptake) and cooking time. Prior to soaking and cooking, a total of 150 seeds for each genotype in both field seasons was placed in paper envelopes and kept at $4{ }^{\circ} \mathrm{C}$ (relative humidity of 75\%) to ensure that seeds maintained a moisture content of $10-12 \%$. Before conducting the water uptake and cooking time experiments, the seed moisture content of each genotype was measured using a Moisture Check Plus meter (Deere and Company, Moline, IL, USA). To measure the hydration properties (water uptake) of the common bean genotypes, 30 moisture equilibrated seeds were weighed and then soaked in distilled water (1:8 raw seed weight/water weight) for 12 hours at room temperature. The seeds were then drained, bloated dry, and reweighed to compute water uptake based on the following equation: 


$$
\text { Water uptake }=\frac{\text { Seed weight after soaking }- \text { Seed weight before soaking }}{\text { Seed weight before soaking }} \times 100
$$

To quantify cooking time, a total of 25 soaked seeds from each genotype were cooked using a pin-drop Mattson cooking device (Customized Machining and Hydraulics Co., Winnipeg, Canada). The Mattson cooker utilizes $2 \mathrm{~mm}$ stainless steel rods (each weighing $70 \mathrm{~g}$ ) positioned above the center of each common bean seed during the cooking process. The Mattson cooker is then lowered into a four-liter stainless steel beaker containing 1.8 liters of boiling distilled water heated over a Waring SB30 portable burner. Cooking time was recorded as the number of minutes for taken for $80 \%$ of the pin-rods (i.e. 20 out of 25) to puncture through seeds under a steady boil at $100^{\circ} \mathrm{C}^{50}$.

Statistical analyses and data visualization. The analysis of variance (ANOVA) for all sources of variation was conducted using PROC MIXED statement using the statistical analysis software, SAS v9.4 ${ }^{51}$. Pearson correlation coefficients among traits across locations and years were determined using the PROC CORR statement also in SAS. The variance components for estimating broad sense heritability $\left(\mathrm{H}^{2}\right)$ for all traits were computed using the PROC VARCOMP statement in SAS v9.4 using the restricted maximum likelihood estimation method $^{51}$. The statistical model used for the ANOVA and computing variance components in SAS v9.4 is shown below:

$$
\begin{aligned}
\mathrm{Y}_{i j k m}= & +\mathrm{G}_{i}+\mathrm{L}_{j}+\mathrm{S}_{k}+\mathrm{GL}_{i j}+\mathrm{GS}_{i k}+\mathrm{LS}_{j k} \\
& +\mathrm{GLS}_{i j k}+\operatorname{rep}(\mathrm{LS})_{j k m}+\varepsilon_{i j k m}
\end{aligned}
$$

where $\mathrm{Y}_{i j k m}$ is the response variable like yield or cooking time of the $i^{\text {th }}$ common bean genotype in the $m^{\text {th }}$ replication of the $j^{\text {th }}$ location in the $k^{\text {th }}$ season; $\mu$ is the grand mean; $\mathrm{G}_{i}, \mathrm{~L}_{j}, \mathrm{~S}_{k}, \mathrm{GL}_{i j}, \mathrm{GS}_{i k}, \mathrm{LS}_{j k}$, GLS $\mathrm{S}_{i j k}$ are effects of the $i^{\text {th }}$ genotype, $j^{\text {th }}$ location, $k^{\text {th }}$ season and their respective interactions; rep(LS) ${ }_{j k m}$ denotes the effect of the $m^{\text {th }}$ replication nested within the interaction term of the $j^{\text {th }}$ location and $k^{\text {th }}$ season; $\varepsilon_{i j k m}$ is the error term assumed to be normally distributed with mean $=0$. For the ANOVA in $S A S$, the effects of $G_{i}, L_{j}$, and $\mathrm{GL}_{i j}$ were treated as fixed. The remaining effects were treated as random to estimate Fisher's protected least significant difference (LSD) and to compare means among the common bean genotypes, as well as the locations for each phenotype. To generate the variance components for computing broad-sense heritability estimates $\left(\mathrm{H}^{2}\right)$ all effects in the statistical model above were treated as random. Broad sense heritability $\left(\mathrm{H}^{2}\right)$ was computed using the equation below:

$$
\text { Heritability }=\frac{\operatorname{Var}(\mathrm{G})}{\operatorname{Var}(\mathrm{G})+\frac{\operatorname{Var}(\mathrm{GL})}{1}+\frac{\operatorname{Var}(\mathrm{GS})}{\mathrm{s}}+\frac{\operatorname{Var}(\mathrm{GLS})}{1 \mathrm{~s}}+\frac{\operatorname{Var}(\mathrm{Error})}{1 \mathrm{sr}}}
$$

where, $\operatorname{Var}(\mathrm{G})$ is genotypic variance, $\operatorname{Var}(\mathrm{GL})$ is the genotype by location variance, $\operatorname{Var}(\mathrm{GS})$ is the genotype by season variance, $\operatorname{Var}(\mathrm{GLS})$ is the genotype by location by season variance, $\operatorname{Var}$ (Error) is the residual/experimental error variance. The denominators $\mathrm{l}, \mathrm{s}$, and $\mathrm{r}$ represent number of locations, seasons, and field replications respectively.

To visually assess the presence of mega-environments, trait stability, and genotype rankings ${ }^{52}$, a GGE biplot analysis was conducted using the GGEBiplotGUI package ${ }^{53}$ in RStudio. To generate two-way data required for GGE biplot analysis, all location by season combinations for each trait were defined as environments ${ }^{32}$ and the data files were inputted into RStudio to visualize the GGE patterns. All data were tester centered (G+GE) and non-scaled as described in Yan and Tinker ${ }^{32}$. Biplots intended to evaluate test environments and genotypes such as "which-won-where" polygons were drawn with column metric preserving singular value partitioning (SVP). Biplots for evaluating genotype and genotype by environment main effects, such as mean performance vs. stability and genotype rankings were drawn with row metric preserving SVP ${ }^{54}$.

\section{Data availability}

All the relevant data for this research are in the paper and its supplementary information files provided in the online version.

Received: 7 August 2019; Accepted: 31 January 2020;

Published online: 27 February 2020

\section{References}

1. Alexandratos, N. \& Bruinsma, J. World agriculture towards 2030/2050: The 2012 revision. ESA Working paper No. 12-03. Food and Ag. Org. United Nations, Rome (2012).

2. Akibode, C. S. \& Maredia, M. Global and regional trends in production, trade and consumption of food legume crops. Report submitted to the Standing Panel on Impact Assessment (SPIA) of the CGIAR Science Council, FAO, Rome (2011).

3. Uganda Bureau of Statistics. UBOS statistical abstract report for crop area and production. https://www.ubos.org/ (2017). (Accessed on January, $27^{\text {th }} 2019$ ).

4. Kilimo Trust. Development of Inclusive Markets in Agriculture and Trade (DIMAT): The Nature and Markets of Bean Value Chains in Uganda. http://www.undp.org/content/dam/uganda/docs/UNDP\%20Uganda_PovRed\%20-\%20Beans\%20Value\%20Chain\%20 Report\%202013.pdf (2012).

5. Sebuwufu, G., Mazur, R., Ugen, M. \& Westgate, M. Using improved varieties and fertility enhancements for increasing yield of common beans (Phaseolus vulgaris L.) grown by small-landholder farmers in Uganda. Afri. J. Agric. Res. 10, 4795-4805 (2015).

6. Buruchara, R. et al. Development and delivery of bean varieties in Africa: The Pan-Africa 656 Bean Research Alliance (PABRA) Model. Afri. Crop Sci. J. 19, 227-245 (2011). 
7. Awio, B. et al. Participatory farmers' selection of common bean varieties (Phaseolus vulgaris L.) under different production constraints. Plant Breed. 137, 283-289, https://doi.org/10.1111/pbr.12594 (2018).

8. Beebe, S. E. Common bean breeding in the tropics. Plant Breed. Rev. 36, 357-426, https://doi.org/10.1002/9781118358566.ch5 (2012).

9. Balakrishnan, D. et al. Genotype x environment interactions of yield traits in backcross introgression lines derived from Oryza sativa cv Swarna/Oryza nivara. Front. Plant Sci. 7, 1530, https://doi.org/10.3389/fpls.2016.01530 (2016).

10. Tumwegamire, S. et al. Genotype $\mathrm{x}$ environment interactions for East African orange-fleshed sweet potato clones evaluated across varying eco-geographic conditions in Uganda. Crop Sci. 56, 1628-1644, https://doi.org/10.2135/cropsci2015.10.0612 (2016).

11. Laurie, S. M., Booyse, M., Labuschagne, T. \& Greyling, M. M. Multi-environment performance of new orange-fleshed sweet potato cultivars in South Africa. Crop Sci. 55, 1585-1595, https://doi.org/10.2135/cropsci2014.09.0664 (2015).

12. Masinde, E. M. et al. Genotype by environment interactions in identifying cassava (Manhot esculenta Crantz) resistant to cassava brown streak disease. Field Crops Res. 215, 39-48, https://doi.org/10.1016/j.fcr.2017.10.001 (2018).

13. Asfaw, A., Blair, M. W. \& Struik, P. C. Multi-environment quantitative trait loci analysis for photosynthate acquisition, accumulation, and remobilization traits in common bean under drought stress. Genes Genomes Genet. 5, 579-595, https://doi.org/10.1534/ g3.112.002303 (2012).

14. Carbonell, S. A. M., Filho, J. A. A., Dias, L. A. S., Garcia, A. F. F. \& Morais, L. K. Common bean cultivars and lines interactions with the environments. Sci. Agric. (Piracicaba, Brazil). 61, 169-177, https://doi.org/10.1590/S0103-90162004000200008 (2004).

15. Aseete, P., Katungi, E., Bonabana-Wabbi, J., Birachi, E. \& Ugen, M. A. Consumer demand heterogeneity and valuation of valueadded pulse products: A case of precooked beans in Uganda. Agric. Food Sec. 7, 51, https://doi.org/10.1186/s40066-018-0203-3 (2018).

16. Katungi, E., Kikulwe, E. \& Emongor, R. Analysis of farmers' valuation of common bean attributes and preference heterogeneity under environmental stresses of Kenya. Afr. J. Agric. Res. 10, 2889-2901 (2015).

17. Larochelle, C., Katungi, E. \& Beebe, S. E. Disaggregated analysis of bean consumption demand and contribution to household food security in Uganda. Prepared for the International Center for Tropical Agriculture (CIAT), Cali, Columbia (2015).

18. Legros, G. et al. The energy access situation in developing countries: A review focusing on the least developed countries and subSaharan Africa. World Health Organization (2009).

19. Adkins, E., Oppelstrup, K. \& Modi, V. Rural household energy consumption in the millennium villages in Sub-Saharan Africa. Energy Sustain. Dev. 16, 249-259, https://doi.org/10.1016/j.esd.2012.04.003 (2012).

20. Cichy, K. A., Wiesinger, J. A. \& Mendoza, F. A. Genetic diversity and genome-wide association analysis of cooking time in dry bean (Phaseolus vulgaris L.). Theor. Appl. Genet. 128, 1555-1567, https://doi.org/10.1007/s00122-015-2531-z (2015).

21. Wiesinger, J. A. et al. Demonstrating a nutritional advantage to the fast-cooking dry bean (Phaseolus vulgaris L.). J. Agric. Food Chem. 64, 8592-8603, https://doi.org/10.1021/acs.jafc.6b03100 (2016).

22. Shellie-Dessert, K. C. \& Hosfield, G. L. Implications of genetic variability for dry bean cooking time and novel cooking methods for fuelwood conservation in Rwanda. Ecol. Food Nutr. 24, 195-211, https://doi.org/10.1080/03670244.1990.9991138 (1990).

23. Garcia, R. A. V. et al. QTL mapping for the cooking time of common beans. Euphytica 186, 779-792, https://doi.org/10.1007/ s10681-011-0587-7 (2012).

24. Gyawali, S. et al. 2007. Collaborative breeding with farmers can be effective. Field Crops Res. 101, 88-95, https://doi.org/10.1016/j. fcr.2006.09.013 (2007).

25. Sibiko, K. W., Ayuya, O. I., Gido, E. O. \& Mwangi, J. K. An analysis of economic efficiency in bean production: Evidence from Eastern Uganda. J. Econ. Sustain. Dev. 4, 1-9 (2013).

26. Takusewanya, R., Namayanja, A., Bwogi, G. V., Mwine, J. \& Odong, T. L. Assessment of staking in a climbing bean production system as practiced by smallholder farmers in Uganda. J. Crop Sci. Agron. 2, 18-27 (2017).

27. Kiwuka, C., Bukenya, Z. R., Namaganda, M. \& Mulumba, J. W. Assessment of common bean cultivar diversity in selected communities of Central Uganda. Afr. Crop Sci. J. 20, 149-158 (2012).

28. Okii, D. et al. The genetic diversity and population structure of common bean (Phaseolus vulgaris L.) germplasm in Uganda. Afr. J. Biotech. 13, 2935-2949, https://doi.org/10.5897/AJB2014.13916 (2014).

29. Kelly, J. D., Kolkman, J. M. \& Shneider, K. Breeding for yield in dry bean (Phaseolus vulgaris L.). Euphytica 102, 343-356, https://doi. org/10.1023/A:1018392901978 (1998).

30. Checa, O. E. \& Blair, M. W. Inheritance of yield related traits in climbing beans (Phaseolus vulgaris L.). Crop Sci. 52, 1998-2013, https://doi.org/10.2135/cropsci2011.07.0368 (2012).

31. Yan, W. \& Tinker, N. A. An integrated biplot analysis system for displaying, interpreting, and exploring genotype $\mathrm{x}$ environment interaction. Crop Sci. 45, 1004-1016, https://doi.org/10.2135/cropsci2004.0076 (2005).

32. Yan, W. \& Tinker, N. A. Biplot analysis of multi-environment data: Principles and applications. Can. J. Plant Sci. 86, 623-645, https:// doi.org/10.4141/P05-169 (2006).

33. Singh, S. P., Teran, H., Munoz, C. G. \& Orsono, J. M. Selection for seed yield in Andean intra-gene pool and Andean x Middle American inter-gene pool populations of common bean. Euphytica. 127, 437-444, https://doi.org/10.1023/A:1020317608553 (2002).

34. Beaver, J. S. \& Kelly, J. D. Comparison of selection methods for dry bean populations derived from crosses between gene pools. Crop Sci. 25, 923-926, https://doi.org/10.2135/cropsci1994.0011183X003400010005x (1994).

35. Stanley, D. W. A possible role for condensed tannins in bean hardening. Food Res. Int. 25, 187-192, https://doi.org/10.1016/09639969(92)90136-S (1992).

36. Castellanos, J. Z., Guzmán-Maldonado, H., Acosta-Gallegos, J. A. \& Kelly, J. D. Effects of hardshell character on cooking time of common beans grown in the semiarid highlands of Mexico. J. Sci. Food Agric. 69, 437-443, https://doi.org/10.1002/jsfa.2740690406 (1995).

37. Dickson, M. H. \& Boettger, M. A. Heritability of semi-hard seed induced by low seed moisture in beans (Phaseolus vulgaris L.). J. Amer. Soc. Hort. Sci. 107, 69 (1982).

38. Gloyer, W. O. Hardshell of beans: Its production and prevention under storage conditions. In Proceedings of the Association of Official Seed Analysts of North America. 19/20, 52-55. The Association of Official Seed Analysts (1928).

39. Katuuramu, D. N. Identification of genomic loci underlying nutritional quality traits in common bean (Phaseolus vulgaris L.) and participatory evaluation and selection of nutritionally superior common bean genotypes with farmers. Ph.D. Dissertation. Michigan State University, East Lansing, Michigan, USA (2017).

40. Coelho, C. M. M., Bellato, C. M., Santos, J. C. P., Ortega, E. M. M. \& Tsai, S. M. Effect of phytate and storage conditions on the development of the 'hard-to-cook' phenomenon in common beans. J. Sci. Food Agric. 87, 1237-1243, https://doi.org/10.1002/ jsfa.2822 (2007).

41. Njoroge, D. M. et al. Mechanistic insight into common bean pectic polysaccharide changes during storage, soaking and thermal treatment in relation to the hard-to-cook defect. Food Res. Int. 81, 39-49, https://doi.org/10.1016/j.foodres.2015.12.024 (2016).

42. Yan, W., Kang, M. S., Ma, B., Woods, S. \& Cornelius, P. L. GGE biplot vs. AMMI analysis of genotype-by-environment data. Crop Sci. 47, 643-653, https://doi.org/10.2135/cropsci2006.06.0374 (2007).

43. Yan, W. \& Fregeau-Reid, J. Breeding line selection based on multiple traits. Crop Sci. 48, 417-423, https://doi.org/10.2135/ cropsci2007.05.0254 (2008) 
44. Mubiru, D. N. et al. Climatic trends, risk perceptions, and coping strategies of smallholder farmers in rural Uganda. Working paper, CGIAR Research Program on Climate Change, Agriculture and Food Security. 23 June 2015. Climate Change, Agric. and Food Sci., Copenhagen, Denmark. www.ccafs.cgiar.org. (2015) (Accessed on February, 20 th 2019).

45. Kimbugwe, K. Three-year production sector development plan. Rakai district local government. Production and marketing department. Kampala (2013).

46. Nathan, M. V. \& Gelderman, R. Recommended chemical soil test procedures for the North Central Region. Univ. of Missouri. No. 221. Univ. of Missouri Agric. Exp. Stat., Columbia, Missouri, USA (2012).

47. Katuuramu, D. N. et al. Genome-wide association analysis of nutritional composition-related traits and iron bioavailability in cooked dry beans (Phaseolus vulgaris L.). Mol. Breed. 38, 44, https://doi.org/10.1007/s11032-018-0798-x (2018).

48. Nkalubo, S. T. et al. Breeding for bean anthracnose resistance: Matching breeding interventions with people's livelihoods through participatory variety selection. Uganda J. Agric. Sci. 14, 45-55 (2013).

49. PABRA. PABRA Database. Pan-Africa Bean Research Alliance, Kampala, Uganda. http://database.pabra-africa.org (2016) (Accessed on March, 29 2019 ).

50. Wang, N. \& Daun, J. K. Determination of cooking times of pulses using an automated Mattson cooker apparatus. J. Sci. Food Agric. 85, 1631-1635, https://doi.org/10.1002/jsfa.2134 (2005).

51. SAS Institute. The SAS system for Windows. Release 9.4. SAS Institute Inc., Cary, NC, USA (2013).

52. Yan, W., Hunt, L. A., Sheng, Q. \& Szlavnics, Z. Cultivar evaluation and mega-environment investigation based on GGE biplot. Crop Sci. 40, 597-605, https://doi.org/10.2135/cropsci2000.403597x (2000).

53. Frutos, E., Galindo, M. P. \& Leiva, V. An interactive biplot implementation in R for modeling genotype-by-environment interaction. Stochastic Environ. Res. Risk Assess. 28, 1629-1641, https://doi.org/10.1007/s00477-013-0821-z (2014).

54. Yan, W. Singular-value partition for biplot analysis of multi-environment trial data. Agron. J. 94, 990-996, https://doi.org/10.2134/ agronj2002.0990 (2002).

\section{Acknowledgements}

This research was supported by the Feed the Future Innovation Lab for Collaborative Research on Grain Legumes by the Bureau for Economic Growth, Agriculture, and Trade, U.S. Agency for International Development, under the terms of Cooperative Agreement No. EDH-A-00-07-00005-00 and by the Norman Borlaug Commemorative Research Initiative (U.S. Agency for International Development), by the U.S. Department of Agriculture, Agricultural Research Service. The authors greatly thank farmer group members from Kakindo, Kyamalera, Tugonzagane, Katugezeko, Tweweyo, Tweyunge, Agali-awamu, Kiyovu, and Balitwewunya farmers' groups for their participation and cooperation in this research. The authors thank Weijia Wang, Francisco Santos, Peiyen Kuo, and Diego Crespo for their help with common bean sample handing and cooking.

\section{Author contributions}

D.N.K., J.D.K., and K.A.C. conceived, designed, and implemented the experiments. D.N.K., G.B.L., S.T.N., J.A.W., and K.A.C. performed the experiments and collected data. D.N.K. analyzed the data and wrote the initial draft of the manuscript. All authors read, edited, and approved the final version of the manuscript.

\section{Competing interests}

The authors declare no competing interests.

\section{Additional information}

Supplementary information is available for this paper at https://doi.org/10.1038/s41598-020-60087-2.

Correspondence and requests for materials should be addressed to K.A.C.

Reprints and permissions information is available at www.nature.com/reprints.

Publisher's note Springer Nature remains neutral with regard to jurisdictional claims in published maps and institutional affiliations.

(c) (i) Open Access This article is licensed under a Creative Commons Attribution 4.0 International License, which permits use, sharing, adaptation, distribution and reproduction in any medium or format, as long as you give appropriate credit to the original author(s) and the source, provide a link to the Creative Commons license, and indicate if changes were made. The images or other third party material in this article are included in the article's Creative Commons license, unless indicated otherwise in a credit line to the material. If material is not included in the article's Creative Commons license and your intended use is not permitted by statutory regulation or exceeds the permitted use, you will need to obtain permission directly from the copyright holder. To view a copy of this license, visit http://creativecommons.org/licenses/by/4.0/.

(C) The Author(s) 2020 